\title{
OBSERVATIONS ON THE SURFACE CAPILLARIES IN MAN FOLLOWING CERVICOTHORACIC SYMPATHETIC GANGLIONECTOMY ${ }^{1}$
}

\author{
BY GEORGE E. BROWN² \\ (From the Division of Medicine, The Mayo Clinic, Rochester, Minnesota) \\ (Received for publication February 3, 1930)
}

In the last decade, an impressive amount of evidence has accumulated to indicate that the capillaries are capable of changing their caliber as a response to nervous impulses, independently of the arterioles; that is, that their rôle under certain conditions is active rather than passive. Rouget, in 1873, was the first to present anatomic evidence of the presence of branched cells, which he assumed were contractile, on the endothelial walls of the capillaries. Vimtrup (1922), in Krogh's laboratories, has made histologic studies confirmatory of Rouget's work. The presence of contractile cells on the walls of capillaries has been shown in most tissues of mammals, also in birds, reptiles, and fishes, and more recently, in many tissues in man. Histologic proof is not complete, as contraction of capillaries has been demonstrated in the absence of Rouget cells. Clark and Clark (1925) recently reported that they have not been able to find contractile cells in the capillaries in tadpoles. Stöhr (1926) was only rarely able to demonstrate nerve fibers to the capillary endothelium. Anatomic researches by Vimtrup (1923) on diverse tissues of the human being, including the cutaneous capillaries and venules, have shown the existence of contractile or Rouget cells. Schaley has demonstrated their presence in tissues in the eye of the human being. Beale, in 1860, and Glaser, in 1920, demonstrated in some organs in certain mammals that the capillaries are accompanied by fine, nonmedullated nerve fibers paralleling the capillary. Their connection with the wall of the capillary also has been demonstrated in tissues from some regions.

${ }^{1}$ Read before the Central Society for Clinical Research, Chicago, November 22, 1929.

${ }^{2}$ With the technical assistance of Grace M. Roth. 
The existence of vasomotor fibers to the cutaneous capillaries remains yet to be proved, but as Krogh stated, present histologic methods are probably not yet sufficiently refined to delineate such small sympathetic fibers. Krogh's classical researches on the physiology, and more especially on the number and size of capillaries, in a given unit of tissue has given further impetus to investigation of and information on their autonomous behavior. From the experimental standpoint, then, it can be stated that there is much anatomic and physiologic proof to indicate an independent capillariomotor mechanism, under control of vasomotor nerves, and subject to vasodilator and vasoconstrictor influence.

Several workers in this field, for instance, Kukulka (1920) and Redisch (1924), have advanced the theory that changes in caliber of the capillaries are due largely to chemical effects. This conception has been more extensively studied by Lewis and his associates. They believe there is a dilator substance present in the cells of the tissue, and that capillaries respond to certain forms of injury, including anoxemia and reactive hyperemia, in which there is liberation of a hypothetical dilating substance. These workers presented many convincing experiments and arguments. Krogh accepts this hypothesis, but advanced the opinion that more than one substance may be concerned in the reactions. Other investigators maintained that the change in the size of the capillary is due to variations in pressure dependent on the size of the arterioles. Kuntz (1929) recently summarized the subject by stating: "The data available at present do not afford an entirely adequate explanation of the caliber changes in the capillaries."

The effects of section of the sympathetic nerves and removal of the ganglions have been studied in the frog by several workers. The first effect is dilatation of the capillaries but the caliber is restored after a day, or restoration may be delayed for three months or longer. Even if dilatation of capillaries does not occur after sympathetic ganglionectomy, the state of the vessels is markedly modified, as shown by Drinker (1927) and Krogh, Harrop, and Rehberg (1922). They found that section of the sympathetic nerves produces prompt dilatation of the arteries and arterioles but that dilatation of capillaries is delayed for twenty to thirty minutes. Gabbe (1926) demonstrated in frogs an increase in the number and size of capillaries in muscle after 
division of the sympathetic nerves. Closure of the main arteries, and elimination of the effects of pressure, did not prevent this response. Conversely, it has been shown by many workers that stimulation of the sympathetic nerves produces arterial and capillary contraction, and there is much suggestive evidence that the contraction of arterioles and of capillaries are separate and independent.

With the advent of operative measures in man, in which the sympathetic ganglions are removed, an exceptional opportunity has been afforded to study the effects of sympathetic ganglionectomy on the capillaries of the skin. It has been shown that following the removal of the cervicothoracic and second thoracic sympathetic ganglions in certain cases of Raynaud's disease, of thrombo-angiitis obliterans, and of scleroderma, dilatation of the arterioles of the skin takes place. This response has been measured by the increase which occurs in the surface temperature and by indirect methods for determining the volume of the flow of the blood.

The present study was to determine by microscopic methods whether demonstrable variations in the size and number of capillaries follows sympathetic ganglionectomy. Twenty-four cases in which cervicothoracic ganglionectomy was done by Adson and Craig are included in compiling this report. There were nine cases of Raynaud's disease; twelve cases of scleroderma, nine of which were of the vasomotor type; two cases of thrombo-angiitis obliterans in which there was a vasospastic disturbance, and one case of subacute arthritis, in which there were cold, moist extremities.

\section{METHODS $^{3}$}

The capillaries of the nailfold were examined with the capillary microscope; measurements were made by an eye-piece micrometer; the rates of flow were determined by stopwatch, and by measuring the length of the visible capillary loop the rate of flow in millimeters for each second was calculated. Rates of flow in the capillaries, in excess of $1.5 \mathrm{~mm}$. for each second, are impossible to measure, and rates in excess of this

\footnotetext{
${ }^{3}$ The preoperative and postoperative observations in all cases were made on the same finger and on the same group of capillaries. Drawings were made for purposes of identification. The measurements of the width of the capillary represent the width of the column of blood in the capillary; the wall of the capillary is invisible.
} 
are indicated as simply more than $1.5 \mathrm{~mm}$. for each second. Determinations of surface temperature were carried out with thermocouples, a method embracing an accuracy cf approximately $0.1^{\circ} \mathrm{C}$.

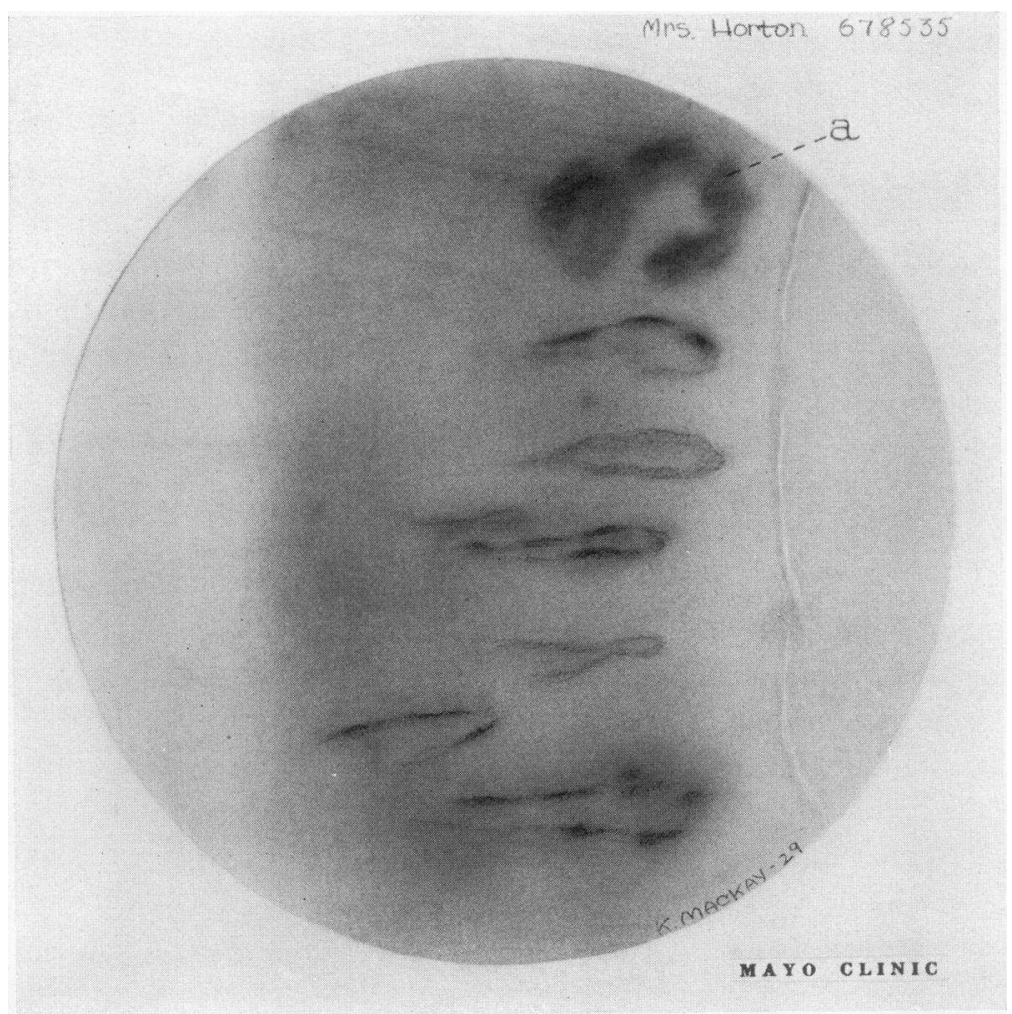

Fig. 1. Capillaries of the Nailfold in a Case of Advanced Raynaud's DiSEASE

The blood appears segmented. The loss of tone is evident in the marked dilatation of several capillaries.

\section{Raynaud's disease}

Raynaud's disease, in a well developed form, is characterized by attacks of pallor or cyanosis in the hands and feet, and occasionally in other acral areas. An attack usually is induced by cold, less frequently by psychic stimulation, and the attendant phenomena have a 
symmetric distribution. The majority of cases occur in young females, usually of asthenic build and with other anatomic features of inferior constitution. The capillaries of the nailfold have been studied intensively in this disease by Parrisius (1921) and by Brown (1925). During the attacks of pallor the capillaries are incompletely filled, many loops are invisible, the flow of blood in the capillary loops ceases, and the blood which is visible has a cyanotic hue. The degree of pallor depends on the completeness of the constriction of the capillaries and the small venules. All gradations in pallor, varying from death-like colorlessness to mild grades of pale cyanosis are observed. The transition from the stage of pallor to cyanosis is frequently imperceptible. There is gradual but incomplete relaxation of the arterioles, which previously have been contracted. Segments of cells pass into capillary loops and frequently retrograde flow from the venules is observed; the capillaries slowly dilate and become distended with markedly cyanotic blood (fig. 1). More capillaries are opened. The stage of rubor, or recovery, which can be obtained by exposing the patient to elevated temperature, signalizes the relaxation of the arteriolar spasm, the resumption of rapid flow in the capillaries, and the transition of the cyanotic blood to blood of a bright red color; many capillaries become visible.

In spite of many observations, on a large number of cases of Raynaud's disease, it has been impossible to state decisively whether or not the independent contraction or dilatation of the capillaries and of arterioles is based on a neurogenic mechanism. However, there is much to suggest that this mechanism exists. This much is certain: in the cyanotic stage of Raynaud's disease, there is independent behavior of the arterioles and of the capillaries; the arterioles are somewhat contracted and the capillaries, dilated. It is a common clinical observation that in some subjects who have had attacks of Raynaud's disease for many years, recovery of the "normal" color of the skin between attacks becomes increasingly difficult, and eventually the hands become more or less permanently cyanotic. Mild degrees of puffiness, or a nonpitting form of edema may supervene. These observations suggest permanent impairment of tonus in the surface capillaries, which may be due to increased concentration of some vasodilating agent, perhaps a histamine-like substance, as 
suggested by Lewis. The chemical factor apparently becomes predominant and maintenance of tonus of the capillaries is seriously and perhaps permanently impaired. In the arterioles there is increased tonus, as is shown by the fairly constant low temperatures of the skin. There is disassociation of behavior of the arterioles and of the capillaries.

There is every reason to believe that the basis of the vascular disturbance in Raynaud's disease is due to increased stimulation of the sympathetic apparatus. This is manifested not only in the behavior of the surface vessels, but also in the sweat glands, as evinced by local hyperhidrosis. Information on the neurogenic basis of the vascular spasm in Raynaud's disease is furnished by the frequent initiation of attacks by excitement and by psychic or emotional trauma. We have witnessed this in many instances; on our coming into the room to carry out venipuncture on these patients, attacks of pallor would be initiated before puncture of the skin had occurred. The recent work of Lewis (1929) seems to have thrown some doubt on the vasomotor basis of some cases of Raynaud's disease. He is inclined to think, from his experiments, that there is a variety of Raynaud's disease which is due to some abnormality of the muscle of the small arterioles. The evidence presented, however, is not convincing, for his procedure for interrupting the vasomotor fibers to the fingers was by blocking the peripheral nerves with procaine. Such interruption may be far from complete. In the present state of knowledge, it is impossible to say that all of the sympathetic fibers are conveyed to the periphery through the spinal nerves. Many fibers may be conducted along the adventitial sheaths of the arteries. That this is probably true is borne out by the fact that occasionally the improvement obtained in cases of Raynaud's disease by perivascular sympathetic neurectomy is only partial. The most convincing evidence concerning the vasomotor basis of Raynaud's disease is the complete cessation of spasm in the surface vessels of the feet following lumbar ganglionectomy. Many of these cases have been followed over periods of three or more years.

In the advanced cases of Raynaud's disease, changes in the capillaries, following cervicothoracic ganglionectomy, were fairly typical (table 1, fig. 2). There was decrease in the caliber of the capillaries in every instance, although moderate degrees of dilatation still persisted. The average decrease was from 0.07 to $0.03 \mathrm{~mm}$. for the group. A 
TABLE 1

Observations on surface capillaries before and after sympathetic ganglionectomy in cases of Raynaud's disease

\begin{tabular}{|c|c|c|c|c|c|c|c|c|c|c|}
\hline \multirow[b]{2}{*}{ 己ુ } & \multirow{2}{*}{ 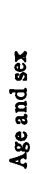 } & \multicolumn{2}{|c|}{$\begin{array}{l}\text { Caliber of } \\
\text { visible } \\
\text { capillaries } \\
\text { (average) }\end{array}$} & \multicolumn{2}{|c|}{$\begin{array}{l}\text { Open loops in } \\
\text { each square } \\
\text { millimeter of } \\
\text { surface area }\end{array}$} & \multicolumn{2}{|c|}{$\begin{array}{l}\text { Flow in } \\
\text { capillary loop, } \\
\text { millimeter for } \\
\text { each second }\end{array}$} & \multicolumn{2}{|c|}{$\begin{array}{c}\text { Surface } \\
\text { tempera- } \\
\text { ture }\end{array}$} & \multirow[t]{2}{*}{ Comment } \\
\hline & & Before & After & Before & After & Before & After & $\begin{array}{l}\text { Be- } \\
\text { fore }\end{array}$ & After & \\
\hline & & $m m$. & $m m$. & & & & & ${ }^{\circ} \mathrm{C}$. & ${ }^{\circ} \mathrm{C}$. & \\
\hline 1 & $\begin{array}{l}30 \\
\text { F. }\end{array}$ & 0.08 & 0.05 & $5-10$ & $16-18$ & 0.09 & $>1.5$ & 23.6 & 27.8 & $\begin{array}{l}\text { History of trouble for nine } \\
\text { years, pallor, cyanosis, pain, } \\
\text { minute dry ulcers }\end{array}$ \\
\hline 2 & $\begin{array}{l}33 \\
\text { F. }\end{array}$ & 0.08 & 0.03 & $8-10$ & $12-14$ & 0.019 & 0.20 & 22.8 & 30.7 & $\begin{array}{l}\text { History of trouble for seven- } \\
\text { teen years, coldness, cyano- } \\
\text { sis, pain, hyperesthesia, no } \\
\text { ulcers }\end{array}$ \\
\hline 3 & $\begin{array}{l}20 \\
\text { F. }\end{array}$ & 0.05 & 0.02 & $\mid 10-12$ & $20-22$ & 0.004 & 0.57 & 723.2 & 32.9 & $\begin{array}{l}\text { History of trouble for four } \\
\text { years, pallor, cyanosis, pain } \\
\text { in hands, no ulzers }\end{array}$ \\
\hline 4 & $\begin{array}{l}40 \\
\text { F. }\end{array}$ & 0.07 & 0.03 & $5-6$ & $14-16$ & 0.06 & 0.33 & $3|23.7|$ & 30.3 & $\begin{array}{l}\text { History of trouble for six } \\
\text { years, pallor, cyanosis } \\
\text { ulcers, pain in fingers of both } \\
\text { hands }\end{array}$ \\
\hline 5 & $\begin{array}{l}26 \\
\text { F. }\end{array}$ & 0.08 & 0.05 & $5-6$ & $16-18$ & 0.05 & $>1.5$ & 20.6 & 529.1 & $\begin{array}{l}\text { History of trouble for seven } \\
\text { years; attacks of extreme } \\
\text { cyanosis of hands and feet } \\
\text { pain, ulcers, advanced case }\end{array}$ \\
\hline 6 & $\begin{array}{l}25 \\
\text { F. }\end{array}$ & 0.08 & 0.03 & 10 & 15 & 0.005 & $>1.5$ & $|27.4|$ & $\mid 30.7$ & $\begin{array}{l}\text { Advanced case, cutaneous } \\
\text { ulcers, pain, recovery of } \\
\text { color difficult to obtain }\end{array}$ \\
\hline 7 & $\begin{array}{l}31 \\
\text { F. }\end{array}$ & 0.05 & 0.02 & $8-10$ & $12-15$ & 0.005 & $>1.5$ & 24.9 & $\mid 34.1$ & $\begin{array}{l}\text { History of trouble for eighteen } \\
\text { months, blanching, numb- } \\
\text { ness, pain in fingers of both } \\
\text { hands }\end{array}$ \\
\hline 8 & $\begin{array}{l}30 \\
\text { F. }\end{array}$ & 0.05 & 0.02 & & $12-15$ & 0.09 & $>1.5$ & 30.5 & 32.6 & $\begin{array}{l}\text { History of trouble for seven } \\
\text { years, color-changes, ulcers, } \\
\text { early scleroderma }\end{array}$ \\
\hline 9 & $\begin{array}{l}35 \\
\text { F. }\end{array}$ & 0.10 & 0.05 & $6-9$ & $11-13$ & 0.002 & 0.10 & 024.0 & $\mid 28.6$ & $\begin{array}{l}\text { History of trouble for two } \\
\text { years, color-changes, pain, } \\
\text { three ulcers of fingers with } \\
\text { early scleroderma }{ }^{1} \text { shanges } \\
\text { in distal parts of fingers }\end{array}$ \\
\hline
\end{tabular}

significant increase took place in the number of visible loops for each square millimeter of surface area of skin. The number of loops in 
different given areas of skin, before operation, varied from five to ten, and after operation, from twelve to twenty. This increase was noted in every case. There was definite change in the flow in the capillary loops. Instead of the broken, segmented, halting type of flow, the

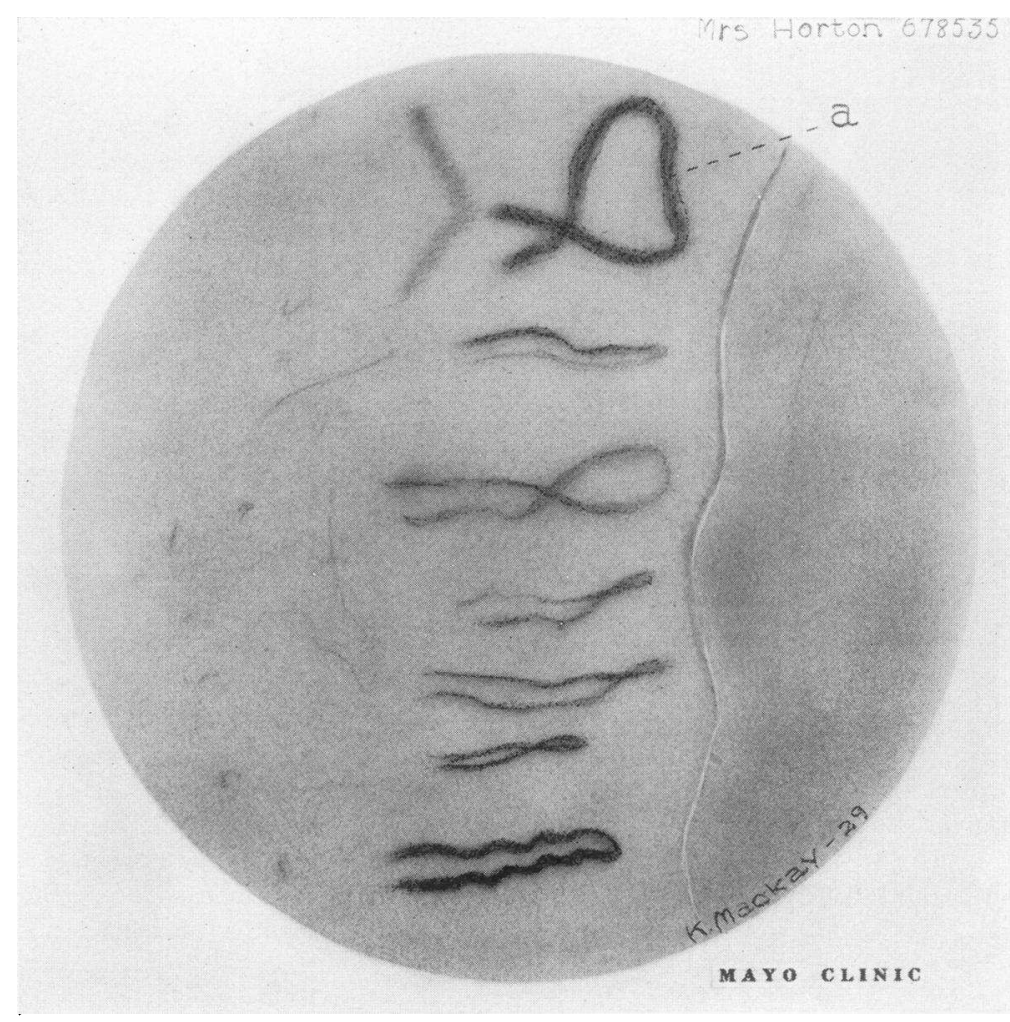

Fig. 2. Capillaries of the Nailfold after Sympathetic Ganglionectomy. Same Group as in Figure 1

There is narrowing of the visible capillaries. More capillaries are visible. The flow is rapid and regular.

flow was accelerated. Interruption and segmentation of the flow was unusual, and the color of the capillary blood at room temperature was bright red. The average value for the rates of flow in the capillaries for the group increased from 0.03 to a rate in excess of $0.95 \mathrm{~mm}$. for each 
second. When these patients were exposed to lowered degrees of local and environmental temperature $\left(15\right.$ to $20^{\circ} \mathrm{C}$.) the capillary flow was distinctly retarded. However, complete stasis, such as that which occurs with the slightest decrease in environmental temperature in cases in which operation is not done, was not observed. The increased surface temperature which occurs uniformly in these cases following operation and which averaged $6.2^{\circ} \mathrm{C}$. for the entire group studied, indicates conclusively dilatation of the arterioles. The subpapillary venules, which before operation were distended and intensely blue and contributed largely to the cyanotic color of the skin, became invisible.

\section{Scleroderma}

This group represents eight distinct and selected cases of scleroderma four of which were characterized by an early history of all the characteristic phenomena of Raynaud's disease. Attacks of pallor and cyanosis in the extremities, induced by cold, have been the rule. Following a variable period, the skin has become thickened, motion of the fingers has become impaired, and, as the disease has advanced, pigmentation, atrophy, and trophic changes have appeared. These changes have affected the hands in the greatest degree, and usually in lesser degree the arms, face, back, legs, and feet. The vasomotor phenomenon usually has continued to be present during the stage of the development of the scleroderma. Chronic cyanosis of the extremities, such as that seen in Raynaud's disease, has been absent. Recovery from the attacks of spasm has been the rule. The studies of capillaries in this group of cases have been carried out by Brown and O'Leary (1925) and they confirm the opinion held by Cassirer (1912), by Leriche and Fontaine (1927) and by others, namely, that there is a form of scleroderma which is probably secondary to vasomotor disturbances of the type seen in Raynaud's disease.

I have observed that the so-called clinical condition designated scleroderma is a cutaneous disturbance secondary to many diseases, and that it occurs in cases of thrombo-angiitis obliterans, chronic arthritis, Raynaud's disease, and dermatomyositis. There is, no doubt, a primary form of scleroderma; four such cases were included in this series. 
Examination of the cutaneous capillaries in the cases of scleroderma can be summarized. (1) There was a sharp diminution of the number of open capillaries for each unit area of skin. (2) Large, distorted, irregular, dilated capillary loops were present, the so-called giant capillaries. (3) Sharp slowing of the flow with slight change in the

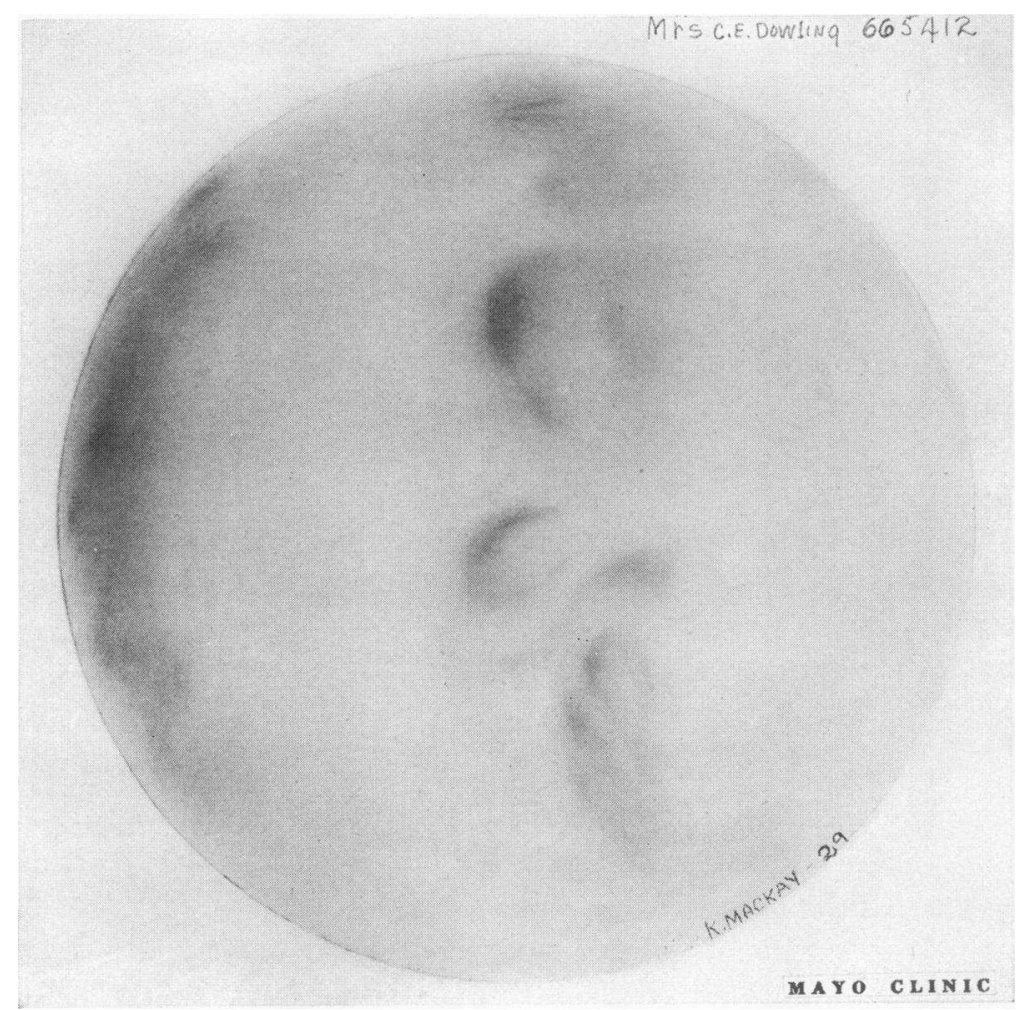

Fig. 3. Capillaries of the NaIlfold in a Case of Scleroderma

The capillary loop is large and distorted. There is marked decrease in the number of visible loops.

environmental temperature took place. Stasis, with cyanotic capillary blood or irregular, intermittent flow could be induced easily by minor degrees of cold. (4) There was marked impairment in the transparency of the skin, which made impossible, with the best forms of illumination, clear definition of outlines of the capillaries; many of 
TABLE 2

Observations on surface capillaries before and after sympathetic ganglionectomy in cases of scleroderma

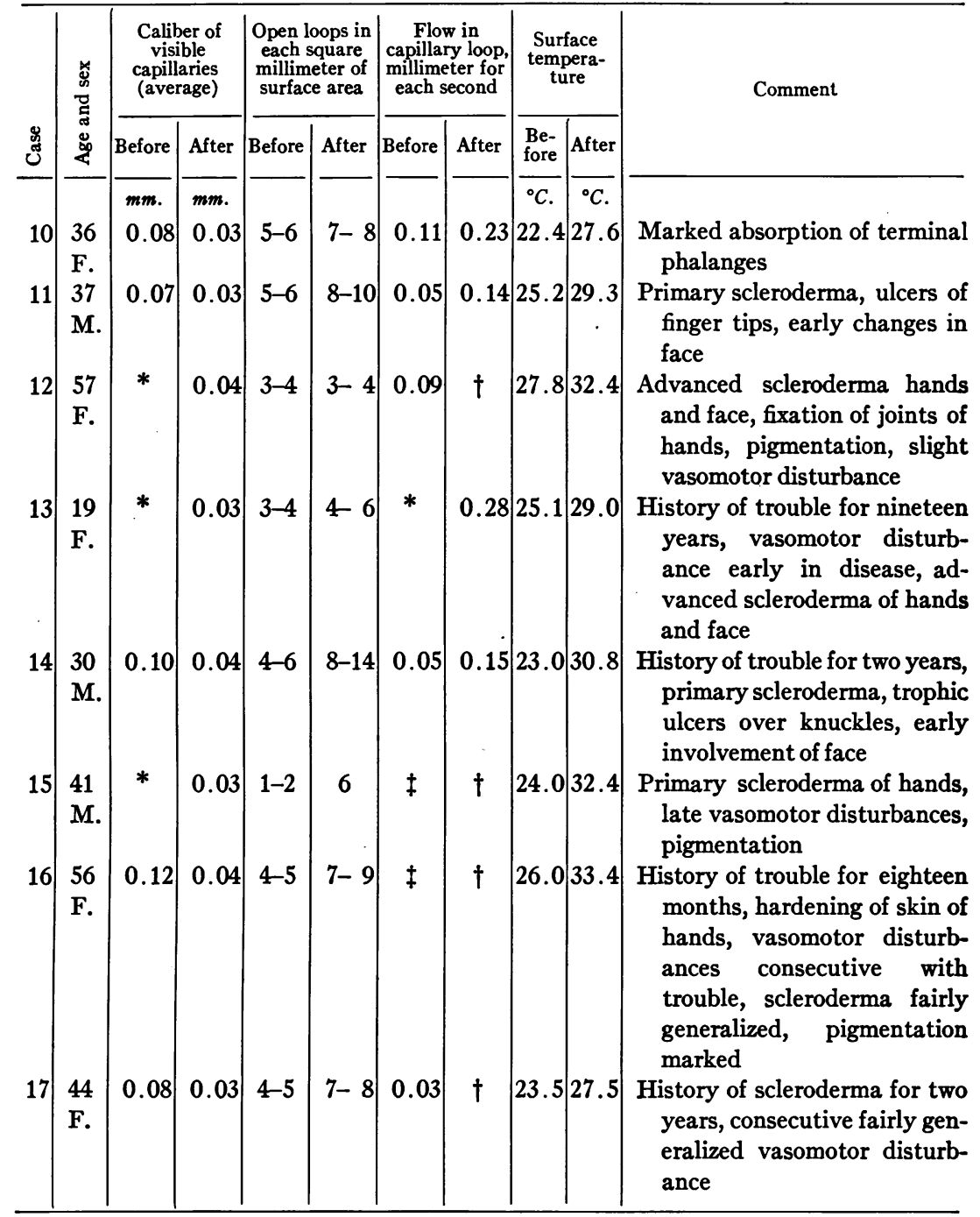

* Impossible to determine.

$\dagger$ More than 1.5.

$\ddagger$ Slow and indistinct. 
TABLE 2-Concluded

\begin{tabular}{|c|c|c|c|c|c|c|c|c|c|c|}
\hline \multirow[b]{2}{*}{ 导 } & \multirow{2}{*}{ 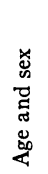 } & \multicolumn{2}{|c|}{$\begin{array}{l}\text { Caliber of } \\
\text { visible } \\
\text { capillaries } \\
\text { (average) }\end{array}$} & \multicolumn{2}{|c|}{$\begin{array}{l}\text { Open loops in } \\
\text { each square } \\
\text { millimeter of } \\
\text { surface area }\end{array}$} & \multicolumn{2}{|c|}{$\begin{array}{c}\text { Flow in } \\
\text { capillary loop, } \\
\text { millimeter for } \\
\text { each second }\end{array}$} & \multicolumn{2}{|c|}{$\begin{array}{l}\text { Surface } \\
\text { tempera- } \\
\text { ture }\end{array}$} & \multirow{2}{*}{ Comment } \\
\hline & & Before & After & Before & After & Before & After & $\begin{array}{l}\mathrm{Be}- \\
\text { fore }\end{array}$ & After & \\
\hline & & $m m$ & $m m$. & & & & & ${ }^{\circ} \mathrm{C}$ & ${ }^{\circ} \mathrm{C}$. & \\
\hline 18 & $\begin{array}{l}24 \\
\text { M. }\end{array}$ & 0.20 & 0.06 & $2-3$ & $3-4$ & $f$ & $t$ & 27.4 & & $\begin{array}{l}\text { History of trouble for fifteen } \\
\text { years, vasomotor disturb- } \\
\text { ance of hands and feet, grad- } \\
\text { ually developing sclero- } \\
\text { dermal changes }\end{array}$ \\
\hline 19 & $\begin{array}{l}34 \\
\text { M. }\end{array}$ & 0.07 & 0.04 & $5-6$ & $7-8$ & 0.07 & $t$ & 25.6 & 30.6 & $\begin{array}{l}\text { History of trouble for eight } \\
\text { years, vasomotor disturb- } \\
\text { ance of hands and feet, grad- } \\
\text { ual sclerodermal changes }\end{array}$ \\
\hline 20 & $\begin{array}{l}37 \\
\mathrm{~F} .\end{array}$ & 0.11 & 0.05 & $3-4$ & 10 & 0.10 & $\dagger$ & 27.8 & 38.2 & $\begin{array}{l}\text { History of trouble for thirteen } \\
\text { years, vasomotor disturb- } \\
\text { ances of hands, scleroderma } \\
\text { of the fingers and arms and } \\
\text { slight involvement of skin } \\
\text { over face and neck, small dry } \\
\text { ulcers of finger and of feet, } \\
\text { pigmentation, mild Ray- } \\
\text { naud's disease }\end{array}$ \\
\hline 21 & $\begin{array}{l}50 \\
\text { F. }\end{array}$ & 0.18 & 0.05 & $3-4$ & $8-10$ & $*$ & $t$ & 21.5 & 33.3 & $\begin{array}{l}\text { History of trouble for one year, } \\
\text { early trophic ulcers of fingers, } \\
\text { partial fixation of joints, } \\
\text { vasomotor disturbances }\end{array}$ \\
\hline
\end{tabular}

the capillaries were seen as indefinite masses of erythrocytes. This diminished transparency of the skin was a fairly constant finding in the more advanced cases.

After operation several changes were noted (table 2, fig. 4). (1) There was definite narrowing of the lumen of the capillaries, averaging a decrease from 0.11 to $0.05 \mathrm{~mm}$. (2) The number of open capillaries for each square millimeter of skin was increased approximately 50 per cent. (3) The average rate of flow in the capillaries increased from 0.07 to $1.05 \mathrm{~mm}$. for each second. Stasis was not observed under controlled room temperatures, and the segmented or broken, interrupted type of flow, indicating arteriolar spasm, was much less striking or it had entirely disappeared. The capillary blood was red instead of 
cyanotic, and (4) marked improvement in the visibility of the skin has been observed within five days after operation. The outlines of the capillary loops were clearly made out, and their contours could be traced easily, and there was definite change in the form of the loops,

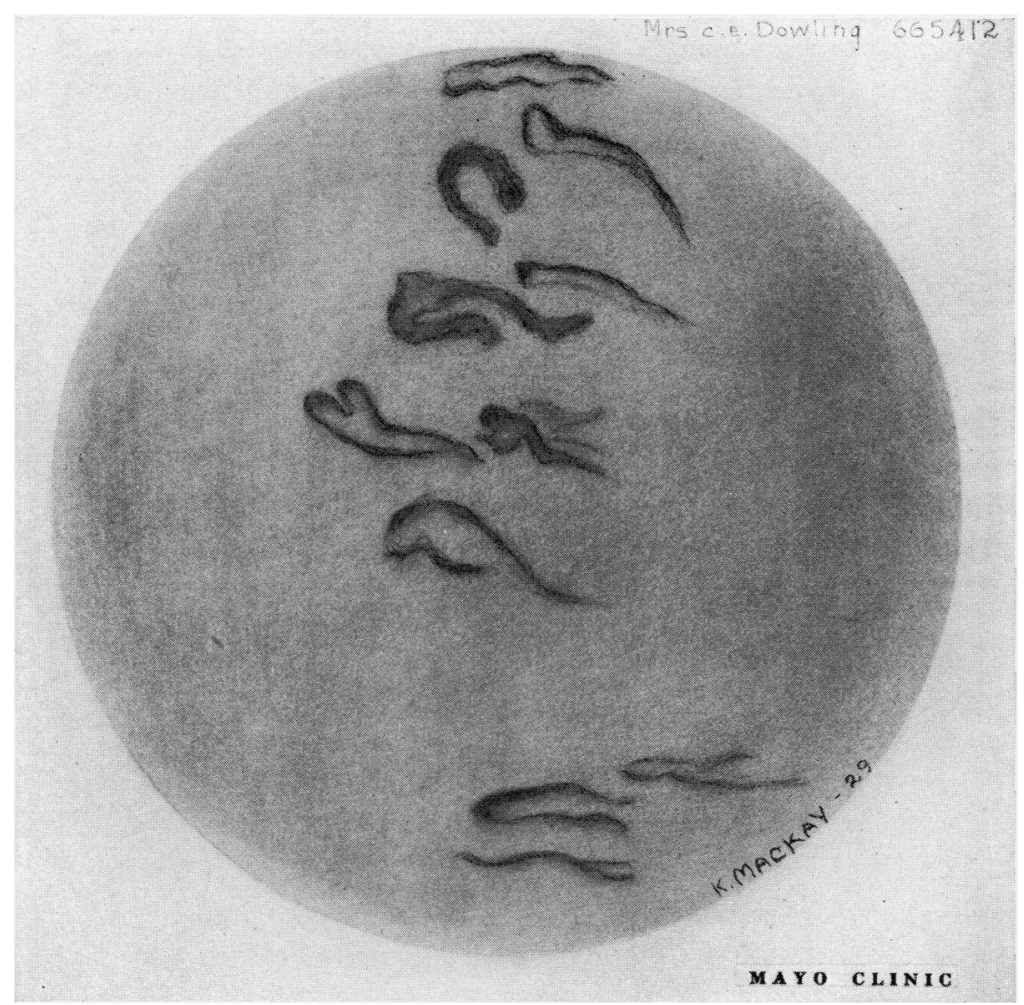

Fig. 4. Same Group of Capillaries as That in Figure 3 after Sympathetic GANGLIONECTOMY

There is an increase in the number of loops and a narrowing of caliber of the capillaries. The capillary flow is rapid and uniform. Marked increase in the transparency of the capillaries is seen.

from an indefinite mass to a bizarre shaped loop with more clearly defined outlines.

It was apparent that the overactive sympathetic vasomotor effects on the arterioles were diminished, as in the uncomplicated cases of 
Raynaud's disease, but not to the same degree. The changes in the transparency of the skin was of the greatest interest. Two possible factors may be responsible for this (1) With the acceleration of the flow in the capillaries and the probable improvement in permeability of the capillaries and metabolism of tissue, certain products or fluids may be removed from the cells in the skin, and (2) the brownish pigmentation which is so commonly present may gradually diminish after operation, thus altering the transparency of the skin.

The surface temperatures were increased after operation in every case. The increase was gradual during the first week after operation. The increase, however, was not of the same magnitude as that which occurred in the uncomplicated cases of Raynaud's disease, and averaged $5.6^{\circ} \mathrm{C}$. for the group. This is easily understood when it is realized that in scleroderma there is organic quantitative diminution in the number of the cutaneous vessels and that new vessels do not open up in the short period of postoperative observation to the same degree as in Raynaud's disease. The increase in the surface circulation was due to the removal of the overactive vasoconstriction of the arterioles and the increase in the number of open capillaries.

\section{Thrombo-angiitis obliterans}

Two cases of thrombo-angiitis obliterans involving the larger arteries of the upper extremities were studied. Associated with the occlusive disease of the arteries was a vasospastic disturbance of the fingers, characterized by attacks of pallor and cyanosis following exposure to lowered temperatures. One or more of the palpable arteries of the wrist were occluded. The spastic disturbances were of great interest. They were undoubtedly secondary and due to the irritative inflammatory disease involving all coats of the arteries. Cases of thrombo-angiitis obliterans, with vasomotor disturbances, are very often erroneously diagnosed as Raynaud's disease in the male, as has been noted by Buerger (1924) and by Allen and Brown (1927).

The capillaries of the nailfold in the cases of thrombo-angiitis obliterans, with a secondary vasospastic disturbance, were essentially different from those in cases of Raynaud's disease (fig. 5). The capillaries were less dilated, there was a larger number for each unit area of skin, and the disturbances of flow were not as pronounced or as easily 
induced with cold as in the cases of Raynaud's disease. Intermittency of the flow, and complete stasis, was not the rule at room temperature. With lowered environmental temperature, mild grades of stasis of the capillary flow were observed, many loops becoming invisible, and the

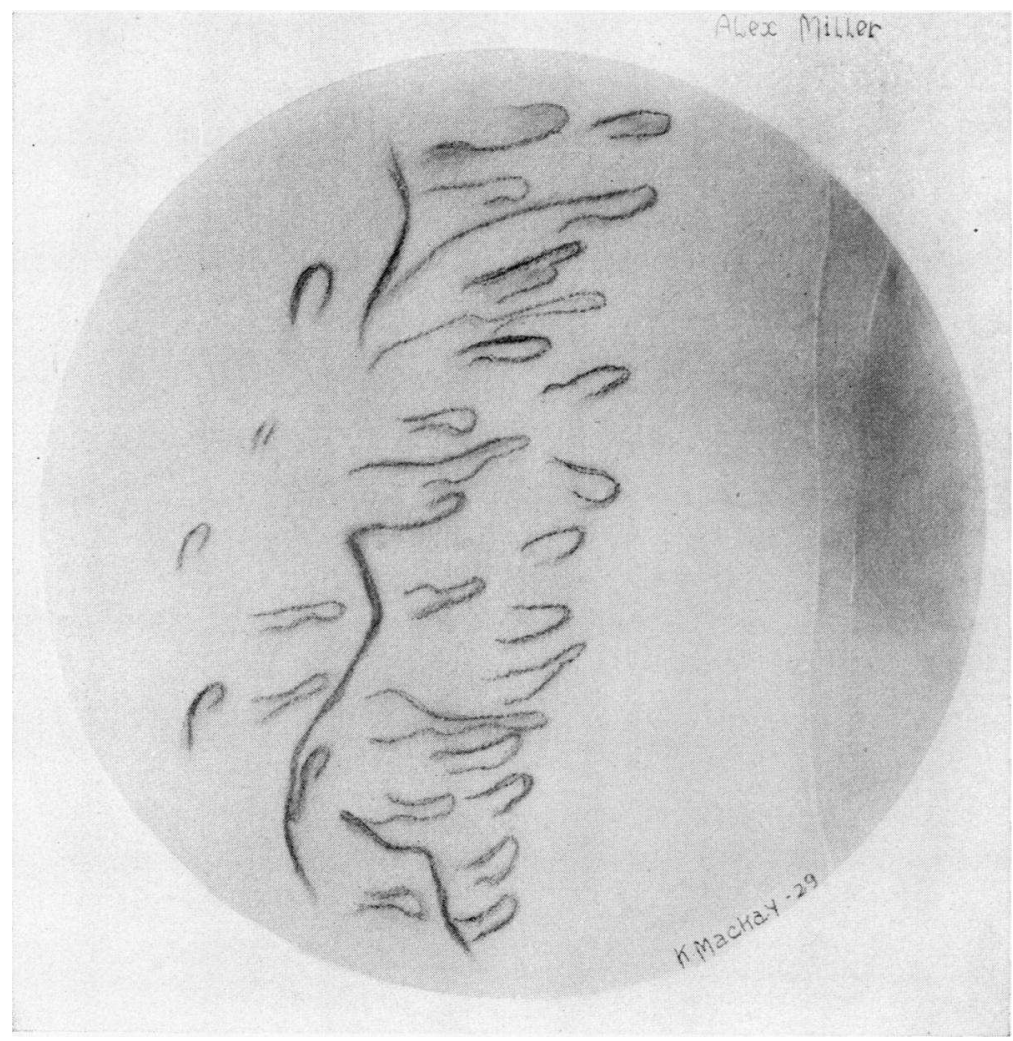

Fig. 5. Capillaries of the Nailfold in a Case of Thrombo-angitis ObLITERANS AfFecting the HaNdS

There is slight dilatation of the capillaries and venules

visible blood becoming cyanotic. Large, dilated, atonic capillaries, such as those observed at room temperature in well developed cases of Raynaud's disease were not observed. The tonus of the capillaries seemed to be maintained better than in Raynaud's disease. Following cervicothoracic ganglionectomy, the surface temperature of 
the fingers and hands were increased, indicating arteriolar dilatation. The surface capillaries were increased in number and for each unit area of skin (fig. 6). The rates of flow in the capillaries were probably accelerated but they could not be measured accurately. With exposure to

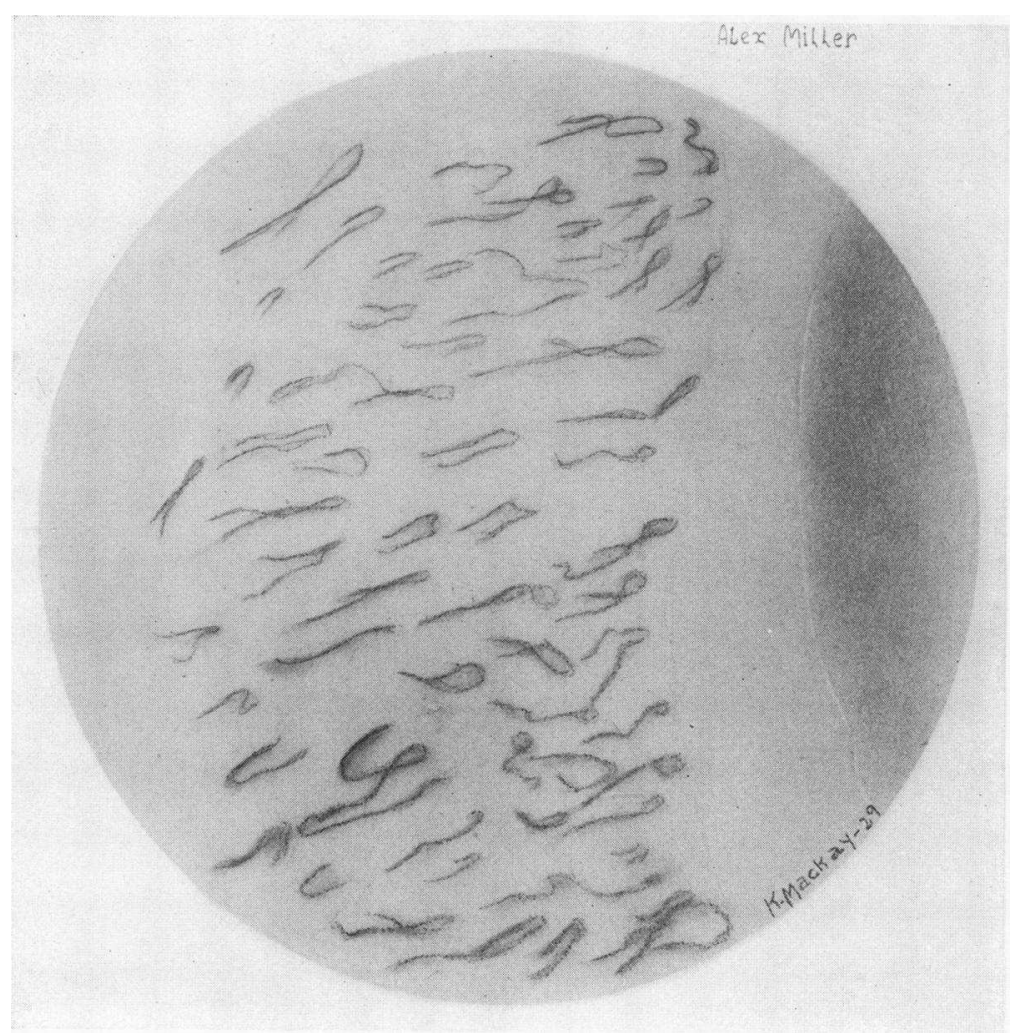

Fig. 6. Same Group of Capillaries as in Figure 5

There is a marked increase in the number of visible capillaries and a slight lessening of the caliber.

lowered environmental temperature, stasis and intermittency of flow was much less noticeable. The changes in the surface vessels correlated well with the clinical improvement observed in these cases. Attacks of cyanosis and pallor disappeared, and there was a greater tendency of the hands to maintain a normal pink color. The rubor of the hands, while in the dependent position, was much less marked. 
The changes that occur in the capillaries in cases of thromboangiitis obliterans are similar to, but less marked than, those which occur in Raynaud's disease. The surface temperature increases sharply immediately after operation. This must be due to the decrease in the exaggerated vasoconstrictor tonus of the arterioles of the collateral circulation.

TABLE 3

Observations on surface capillaries before and after sympathetic ganglionectomy in cases of arthritis and thrombo-angiitis obliterans

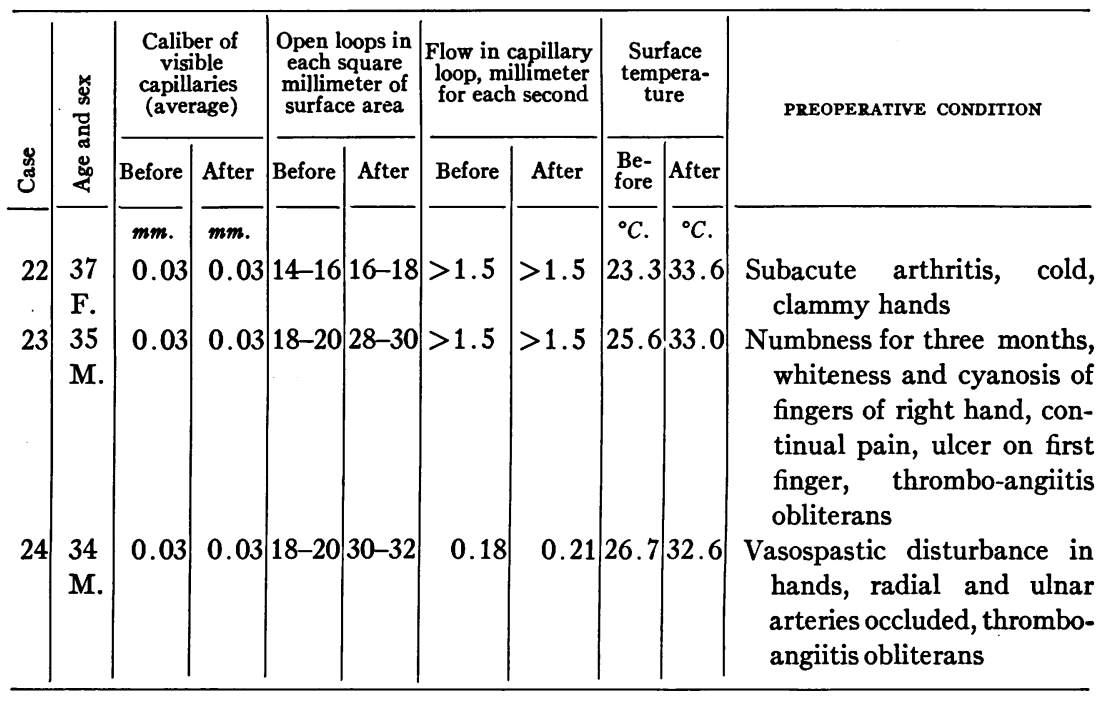

Arthritis

The capillaries in one case of subacute arthritis have been studied before and after cervicothoracic ganglionectomy (table 3). The hands in many of these cases were cool, moist and mildly cyanotic. Excessive sweating of the hands and feet is the rule. There were no significant variations in the size and form of the capillaries of the nailfold, and there was a normal number for the unit area of skin. The capillary flow was easily retarded by chilling. These observations constituted evidence of overstimulation of the sympathetic apparatus. In many respects the appearance of the capillaries of the nailfold was that observed in the so-called normal persons with moist, cool extremities. 
The only significant change noted in the capillaries after operation was an increased number of capillaries for each unit area of skin. There was no measurable increase or decrease in the caliber of the capillaries. No variation in the flaw in the capillaries could be measured, both the preoperative and postoperative rates of flow being too rapid for measurement at room temperature. With lower environmental temperatures, fairly rapid rates of capillary flow were maintained after operation.

These observations in one case of subacute arthritis are contrary to what one would expect. Significant changes in the width of the capillaries could not be demonstrated. This was borne out by the normal pink appearance of the hands after operation. The significant effect of the operation, is the increased surface temperature of the hands.

\section{DISCUSSION}

Removal of the sympathetic ganglions in man does not induce dilatation of the cutaneous capillaries in the extremities of the patients who have been studied. In cases of Raynaud's disease there is loss of tonus of the surface capillaries, and their power of contraction is lost or greatly impaired later in the disease. In this disease there is loss of coördinate action between the arterioles and surface capillaries and venules. There is hypertonus of the arterioles, which is believed to be due to excessive stimulation of the sympathetic nerves, and there is hypotonus in the capillaries and venules which can be explained on a chemical basis. Sympathetic ganglionectomy in man exerts its greatest effects on the arterioles. This can be graded by measuring the sharp and continued elevation of the surface temperatures and by determining the rate of elimination of heat. The color of the normal skin is due largely to the number and size of the surface capillaries and venules and to the color of the contained capillary blood. Cyanotic color of the skin indicates increased exposure of capillary blood containing an increased amount of reduced hemoglobin. The normal pink color of skin would signify a lesser number of capillaries, narrower lumens and blood with oxygen saturation more closely arterial than venous. It follows, therefore, that when the sympathetic vasomotor nerves are interrupted, and the skin changes from a cyanotic to a red 
or pink hue, there must be two reactions in the surface vessels: lessened exposure of capillary blood, either by lessening of the number of open vessels or decrease in their size, and change in the color of the capillary blood by increased rate of flow and resultant changes in its content of oxygen. After operation in Raynaud's disease there is a measurable degree of narrowing of the capillaries, and acceleration of the capillary flow. These effects, we believe, are due to dilatation of the arterioles, with more rapid flow of blood through the capillaries. This causes changes in the chemical environment and probably removal from the tissues of the hypothetic dilator substance. Crawford (1929) in a recent study, has shown that following experimental passive congestion in the capillaries of the ear of the rabbit, there is failure of these vessels to contract from sympathetic stimulation. Crawford advanced the opinion that the accumulation of some dilator substance, as suggested by Ebbecke (1923), Lewis (1929) and others, modifies capillary response. Krogh has noted that reactive hyperemia is induced not only when the flow of blood to a limb is entirely occluded, but also when it is reduced, as occurs in venous congestion. Lewis has shown that dilatation of the cutaneous vessels is active and is not due to changes in pressure. Such dilatation occurs in Raynaud's disease, which simulates venous congestion in the surface vessels. Many explanations have been offered for this phenomenon of dilatation, but none seems as convincing as that advanced by Lewis that there is accumulation of a dilator substance. The fact that the effects of sympathetic ganglionectomy on the capillaries and arterioles are opposed can be explained, I believe, only by a course of reasoning similar to that just explained.

Following sympathetic ganglionectomy, in cases of vasomotor forms of scleroderma, the capillaries are decisively changed. There is a decrease of 50 per cent in the width of the column of capillary blood. There still remains some dilatation, however, for the average width after operation is $0.05 \mathrm{~mm}$., the normal being approximately $0.02 \mathrm{~mm}$. The number of loops is increased, but not comparably to the increase in the cases of Raynaud's disease. This is due to the fact that in scleroderma there is a true organic decrease in the number of surface vessels. In four to six weeks after operation higher surface temperatures are present than one week after operation. This suggests that new vessels 
gradually have opened. The improvement in the transparency of the skin is definite, and probably is an effect of improved lymphatic circulation with removal of fluids or other metabolic products from the skin. There is reason to believe that dilator substances play a part in these forms of scleroderma, but the number of capillaries is so reduced that their dilatation does not markedly affect the color of the skin. It seems likely that there is an additional factor in that the giant forms of capillaries, with marked distortion, represent compensatory efforts to develop a collateral circulation in the skin. This may explain the residual dilatation which remains after operation.

In the one case of arthritis, in which the patient could be considered a control or normal subject, the capillaries were of fairly normal tonus. After operation, no change in the caliber of the capillaries was found, increase in the number of loops was not noted, and the color of the skin likewise did not change. The sole quantitative vascular change was that of arteriolar dilatation as measured by the increase in the surface temperature and in the rate of elimination of heat. These observations on capillaries of normal or increased tonus, which has been subsequently verified by similar observations in two other cases, indicate that in the skin of the human being the abolishment of sympathetic innervation seems to have no visible or measurable effect on the size and number of the capillaries. In this case, the color of the skin resumed a more normal pink, which was due to increased rapidity in the capillary flow.

The impression gained by these studies is that in certain states of disease, in which the tonus of the capillaries was diminished, that of the arterioles was increased. Removal of the sympathetic ganglions has a paradoxic effect. There, tonus of capillaries is increased, and tonus of arterioles is decreased. The former effect can be explained on a chemical basis and the latter on the basis of direct response from dividing the vasomotor nerves.

\section{SUMMARY AND CONCLUSIONS}

Quantitative studies on the capillaries of the skin of human beings have been made both before and after cervicothoracic sympathetic ganglionectomy. Nine cases of advanced Raynaud's disease, four cases of vasomotor forms of scleroderma, four cases of primary 
scleroderma, two cases of thrombo-angiitis obliterans, and one case of arthritis of the hands have been studied.

The operation did not cause dilatation of the capillaries (the usual physiologic effect) in any case. On the contrary, there was consistent narrowing of the dilated atonic capillaries in Raynaud's disease, and an increase in the number of visible capillaries. This could be explained on the basis of a diminished concentration of a theoretic chemical dilator substance in the tissues.

Following sympathetic ganglionectomy in eight cases of vasomotor and primary forms of scleroderma, there was definite reduction in the caliber of the capillaries. The number of open capillaries for each square millimeter of skin increased. There was quantitative evidence of arteriolar dilatation and lessened response on the part of these vessels to cold. Clinical improvement of some degree occurred in every case.

In the cases of thrombo-angiitis obliterans and arthritis, in which the capillaries were of fairly normal caliber and tonus, following operation no change in the width of the capillaries was noted. The intermittent slow flow of cyanotic capillary blood changed to one that was rapid, regular, and of normal color. The number of open capillaries was increased.

The major effect of sympathetic ganglionectomy is exerted on the arterioles. There is a sharp, maintained increase in the surface temperature of the skin of the hand in every case. These studies add some confirmation to the opinions of those who hold to the importance of chemical factors in modifying tonus in the capillaries of the skin of human beings. Chemical control of these vessels seems, under certain conditions, more effective than nervous control.

\section{BIBLIOGRAPHY}

1. Allen, E. V. and Brown, G. E., Am. J. Med. Sci., 1927, clxxiv, 319. Erroneous Diagnosis of Raynaud's Disease in Obliterative Vascular Disease (Thrombo-angiitis Obliterans). I. Vasomotor Disturbances Simulating Raynaud's Disease.

2. Beale, L. S., Phil. Tr. Roy. Soc. London, 1860, cl, 611. On the Distribution of Nerves to the Elementary Fibers of Striped Muscle.

3. Brown, G. E., Arch. Int. Med., 1925, xxxv, 56. The Skin Capillaries in Raynaud's Disease. 
4. Brown, G. E. and O’Leary, P. A., Arch. Int. Med., 1925, xxxvi, 73. Skin Capillaries in Scleroderma.

5. Buerger, Leo, Philadelphia, W. B. Saunders Co., 1924. The Circulatory Disturbances of the Extremities.

6. Cassirer, Richard, Berlin, S. Karger, 1912. Die Vasomotorisch-tropischen Neurosen.

7. Clark, E. R. and Clark, Eleanor L., Am. J. Anat., 1925, xxxv,239. The Development of Adventitial (Rouget) Cells on the Blood Capillaries of Amphibian Larvae.

8. Crawford, J. H., J. Clin. Invest., 1929, vii, 527. The Influence of the Sympathetic Nervous System on the Capillaries During Passive Congestion.

9. Drinker, C. K., J. Physiol., 1927, lxiii, 249. The Permeability and Diameter of the Capillaries in the Web of the Brown Frog ( $R$. temporaria) When Perfused with Solutions Containing Pituitary Extract and Horse Serum.

10. Ebbecke, U., Ergebn. d. Physiol., 1923, xxii, 401. Gefässreaktionen.

11. Gabbe, E., Ztschr. f. d. ges. exp. Med. 1926, li, 728. Über die Wirkung der Sympathischen Innervation auf die Zirkulation und den Stoffaustausch in den Muskeln.

12. Glaser, W., Berlin, J. Springer, 1920, 82-103. Innervation der Blutgefässe. In: L. R. Müller: Das Vegetative Nervensystem.

13. Krogh, August, New Haven, Yale University Press, 1929. The Anatomy and Physiology of Capillaries.

14. Krogh, August, Harrop, G. A. and Rehberg, P. B., J. Physiol., 1922, lvi, 179. Studies on the Physiology of Capillaries. III. The Innervation of the Blood Vessels in the Hind Legs of the Frog.

15. Kukulka, Josef, Ztschr. f. exp. Path. u. Therap., 1920, xxi, 332 Ueber die mikroskopisch feststellbarren, functionellen Veränderungen der Gefässkapillaren nach Adrenalineinwirkung.

16. Kuntz, Albert, Philadelphia, Lea and Febiger, 1929. The Autonomic Nervous System.

17. Leriche, R. and Fontaine, R., Rev. de chir., 1927, lxv, 285. Résultats un Peu Eloignés des Interventions sur le Sympathique dans la Sclérodermie et dans la Dermatite Chronique Atrophiante.

18. Lewis, Thomas, Heart, 1929, xv, 7: Experiments Relating to the Peripheral Mechanism Involved in Spasmodic Arrest of the Circulation in the Fingers, a Variety of Raynaud's Disease.

19. Parrisius, Walter, Deutsch. Ztschr. f. Nervenh., 1921, lxxii, 310. Kapillarstudien bei Vasoneurosen.

20. Redisch, Walter, Klin. Wchnschr., 1924, iii, 1070. Capillaroskopische Untersuchungen bei Vasoneurosen.

21. Rouget, Charles, Arch. d. physiol., 1873, v, 603. Memoire sur le Développement, la Structure et les Propriétés Physiologiques des Capillaires Sanguins et Lymphatiquès. 
22. Schaly, G. A., Quoted by Krogh.

23. Stöhr, Philipp, Jr., Ztschr. f. Zellforsch. u. mikr. Anat., 1926, iii, 431. Mikroskopischer Beitrag zur Innervation der Blutcapillaren beim Menschen.

24. Vimtrup, B., Ztschr. f. d. ges. Anat., 1922, lxv, 150. Beiträge zur Anatomie der Capillaren. I. Utber contractile Elemente in der Gefässwand 'der Blutocapillaren.

25. Vimtrup, B., Ztschr. f. Anat. 1923, lxviii, 469. Beiträge zur Anatomie des Capillaren. II. Weitere Untersuchungen über Contractile Elemente in der Gefasswand der Blutcapillaren. 